\title{
Herpetofauna Distribution and Ecology in East Kutai District, East Kutai, East Kalimantan
}

\author{
Sus Trimurti ${ }^{1}$, Andi Sarina ${ }^{2}$, Lariman $^{3}$ \\ $1,2,3$ ) Biology, Faculty of Mathematics and Natural Sciences, Mulawarman University
}

\begin{abstract}
Herpetofauna consisting of reptiles and amphibians is a group of fauna whose biodiversity potential is rarely known and is not well known by the public. The purpose of this study was to determine the distribution, ecology and diversity of herpetofauna in Mesangat Wetlands. The method used in this research is the Visual Encounter Survey (VES) search method by searching directly for the type of herpetofauna around the predetermined pathway. Field orientation is carried out to determine the location of the observation, the location of the observation is divided into 3 locations (Mesangat Hilir, Tengah and Hulu) in one observation location there are 5 stations (lanes) for herpetofauna observation. Observations were made in the morning starting at $09.00-12.00$ WITA and at night starting at 20.00 - 23.00 WITA. Recorded data related to the number of individuals, activities, time found, environmental parameters and measured SVL if possible. Identified species were found using the identification key book Field Frogs of Borneo Inger and Stuebing (2014) and A Field Guide to the Snakes of Borneo Stuebing, Inger and Lardner (2014). The data were analyzed using Microsoft Excel 2010. The results showed that the distribution of herpetofauna in Mesangat Wetlands was fairly evenly distributed and the ecology of Mesangat Wetlands supported for herpetofauna life and the diversity index value obtained was 1.53 which was classified as medium category.
\end{abstract}

Keywords:- Herpetofauna, Distribution, Ecology, Warmth And Diversity.

\section{INTRODUCTION}

East Kalimantan is one of the provinces in Indonesia which has a high biodiversity, not only the dry land dipterocarp biome but also has extensive wetlands under the adult shells (bush forest) and peat swamp vegetation, besides having a diversity of flora, East Kalimantan also has various kinds of fauna. One of the locations is Mesangat Wetlands in Muara Ancalong which has a high diversity of fauna, especially herpetofauna.

Wetlands itself is an area in the transitional zone between permanently dry land and permanently watery land. The area is always covered with water both in the present or some time in the future within a year
(Kusumawati, 2009). Mesangat Wetlands is one of the habitats of various types of fauna typical and endemic to East Kalimantan such as Crocodylus Siamensis and Tomistoma sclegelelii (Sharney et al, 2019). Mesangat Wetlands began to degrade both flora and fauna, began to lose its potential due to illegal logging activities as well as the conversion of the area into oil palm plantations that damage the flora and fauna habitat, especially herpetofauna.

Herpetofauna which consists of reptiles and amphibians is one type of animal diversity potential that is rarely known and is not well known by the public (Qurniwan and Epilurahman, 2012). This can be seen by the lack of research on reptiles and amphibians in Indonesia. Herpetofauna is one of the components making up an ecosystem that has a very important role, both ecologically and economically (Kusrini, 2003). In addition, herpetofauna also has an important role in maintaining ecosystem balance, because most herpetofauna acts as predators at the level of the food chain in an ecosystem, especially in controlling insect populations (Iskandar, 1998 in Muslim et al, 2018), and can be used as a bio-indicator environmental conditions because they have links and responses to environmental changes (Muslim et al, 2018).

Gibbons et al (2000) state that the lack of breadth of forest canopy closure is one of the main threats to the survival of reptiles and amphibians which can cause extinction. According to the International Union of Conservation of Nature (IUCN) the number of Red List of Threatened Species or herpetofauna species is threatened to increase every year, every living thing is part of the environment having a role to maintain the natural environmental balance, especially the herpetofauna group (Pradana et al, 2019)

Based on the description above, research on "The Distribution and Ecology of Herpetofauna in Mesangat Wetlands in East Kutai Regency, East Kalimantan Province" is important to do because there is still a lack of scientific research and information on herpetofauna in Indonesia, especially in Mesangat Wetlands, Muara Ancalong, East Kutai. This research can be useful as a study as well as efforts in managing areas that become habitats that can affect the distribution, ecology, species richness, diversity and status of the herpetofauna. 


\section{METHODS}

\section{Location and Time of Sampling}

This research was conducted in September 2019 to March 2020 from the survey process, preparation to be completed in the Mesangat Wetlands, Muara Ancalong sub-district, East Kutai district, East Kalimantan Province at the coordinates $\mathrm{N} 00^{\circ} 31^{\prime} 06$ "and E $116^{\circ} 41^{\prime} 47$ "; an altitude of 0 meters above sea level, while data processing and analysis is carried out at the Animal Ecology and Systematics Laboratory, Faculty of Mathematics and Natural Sciences, Mulawarman University, Samarinda, East Kalimantan.

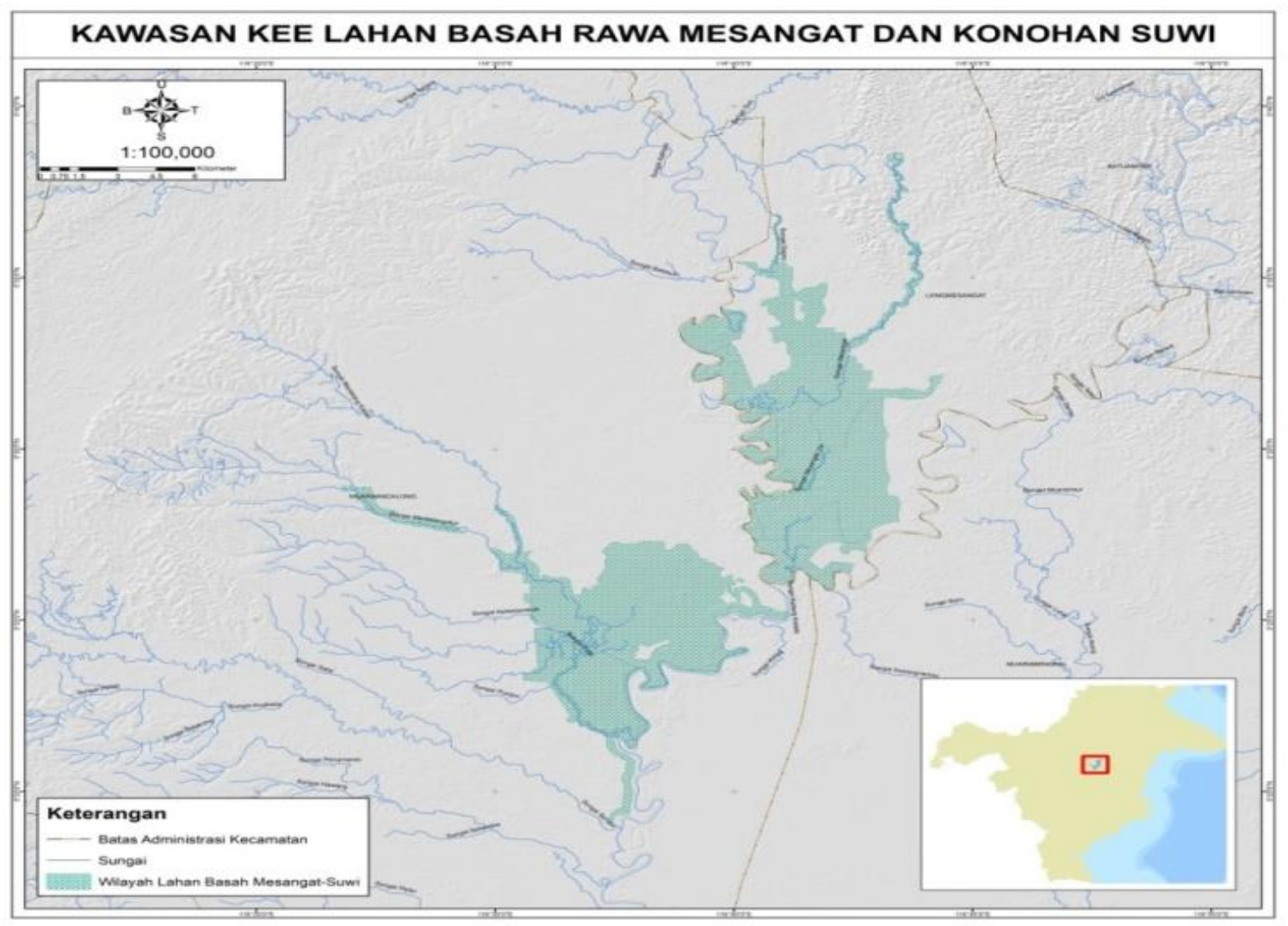

Fig 1:- Location map of Wetlands Mesangat, Muara Ancalong sub-district, East Kutai, East Kalimantan (Source: Ulin Foundation)

\section{Tools and Materials}

The tools used are GPS (Global positioning system), headlamps, cameras, thermohygrometers, fabric meters, turbidimeters, watches / stopwatches, stationery, and machetes. The materials used are raffia, datasheet, plastic clips, 70\% alcohol, cotton, label paper, permanent markers, survey tapes and identification keys.

\section{Herpetofauna Data Collection}

The data collected are herpetofauna data, including: type, number of individuals of each type, size of snout-vent length (SVL), which is the body length from the snout to the cloaca of each type, time when found, activity and number of individuals. Habitat data and environmental parameters, including: point coordinates, location name, substrate, vegetation condition, air temperature, water temperature, water level and humidity.

\section{- Work procedures}

- Field Orientation and Location Determination

Field orientation is carried out before the data collection day aims to find out the conditions in the field related to data collection activities in the field to be carried out, namely, the selection of observation locations and the establishment of a path using GPS. The observation locations were divided into 3 locations, namely Mesangat Hilir Wetlands, Middle Mesangat Wetlands and Mesangat Hulu Wetlands. The observation location (station) is divided into 5 namely station 1 , station 2, station 3, station 4 and station 5. 


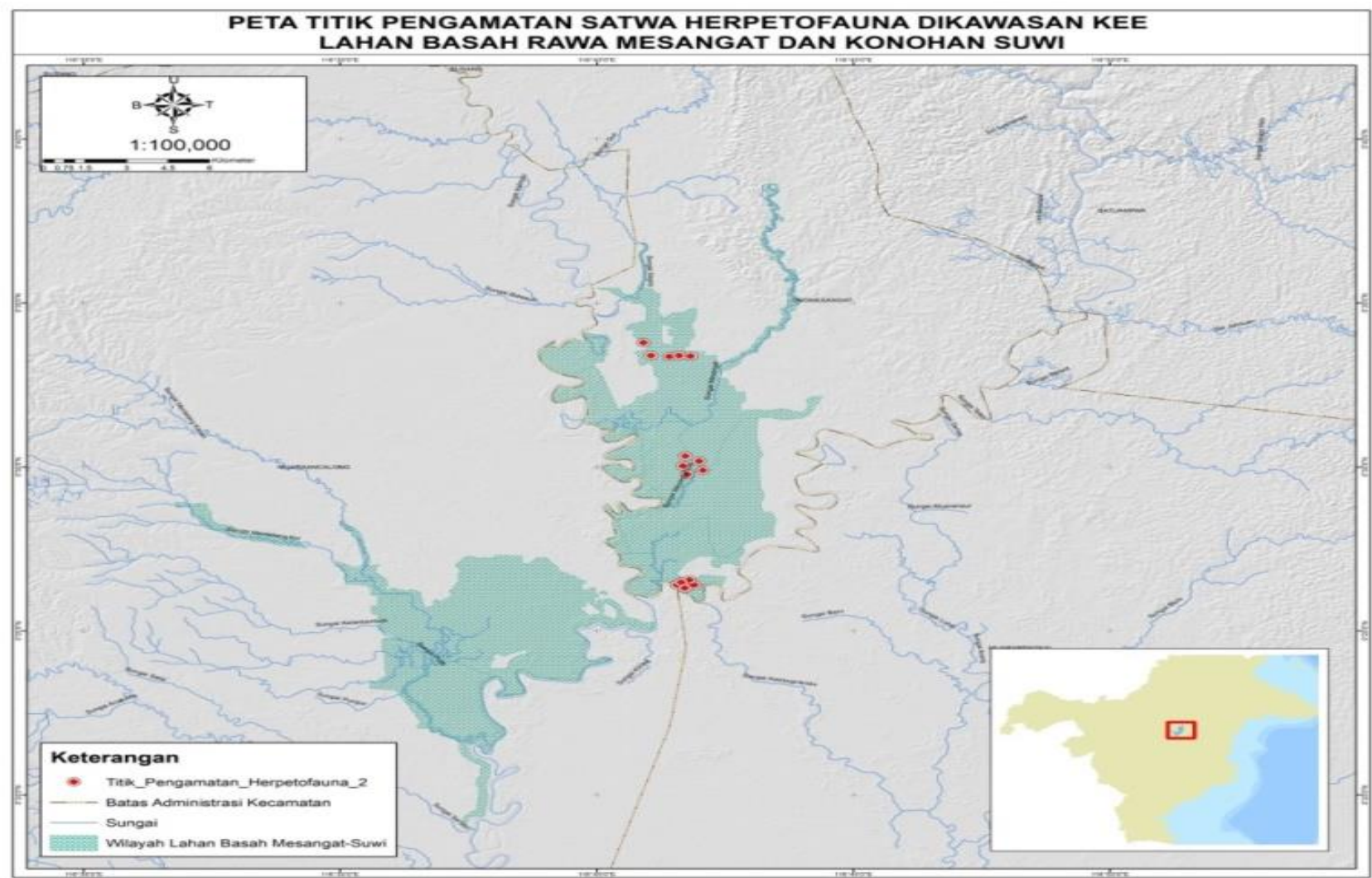

Fig 2:- Location and Herpetofauna Observation Station in Mesangat Wetlands (Source: Ulin Foundation)

\section{Survey Method}

Herpetofauna observations were carried out using the Visual Encounter Survey (VES) search method by directly searching for herpetofauna species around the specified path

\section{Retrieval and data collection Herpetofauna}

Observations are made by tracing the path of observation. In the morning at 09.00-12.00 WITA and at night it is conducted at 20.00-23.00 WITA. When searching and observing herpetofauna using GPS and head lamps. Observations made from point 0 to trace all paths that have been determined. Observation and search for herpetofauna is focused on places that are habitats and may be a hiding place for herpetofauna. Each individual herpetofauna that is seen will be captured and put in a plastic clip / plastic sample to be recorded when found, activity / behavior, type of substrate, and other information which is then labeled.

\section{- Preservation of Herpetofauna Specimens}

Herpetofauna that have been known to be measured and taken as a whole and returned to their natural habitat, while for herpetofauna whose species or species are unknown will be preserved and herpetofauna specimens will be made, maximum 2 individuals will be taken for species that have not yet been identified.

\section{$>$ Identification of Herpetofauna}

Identification of herpetofauna species was carried out using several reptile and amphibian identification books, several field guides introducing amphibian species, namely:
Field Guide Frogs of Borneo Inger and Stuebing (2014) and A Field Guide to the Snakes of Borneo Stuebing, Inger and Lardner (2014).

\section{RESULTS AND DISCUSSION}

Based on the observation location, the highest number of species was found at location 2 (Middle Mesangat) with 9 species and location 3 (Mesangat Hulu) being the least discovered species, namely 4 species. Based on Table 1, the species found in this study were the most numerous species from the order of squamata and anura. Anura Order itself consists of frogs and frogs whose species are most widely distributed and spread throughout Indonesia (Iskandar, 1998). Squamata order spread in almost all parts of Indonesia, this group of animals generally live around or in the waters (Yudha et al, 2016).

The family that has the highest number of species in the Reptilia class is the Scincidae family, namely Emoia atracostata, Eutropis multifasciata and Dasia vittata which are found mostly around litter and trees around the waters. According to Das (2004) in Muslims (2016) the Scincidae family has a distribution in almost all of Indonesia in an open or disturbed area which is mostly covered by litter. the most species in the amphibian class are shown by the family ranidae with the number of species as many as 2 namely Hylarana erythraea and Amnirana nicobariensis according to Mistar (2003) that the ranidae family is abundant in nature and is found in many rivers or large waters. 
ISSN No:-2456-2165

\begin{tabular}{|c|c|c|c|c|}
\hline \multirow[b]{2}{*}{ Parameters } & \multicolumn{3}{|c|}{ Lokasi } & \multirow{2}{*}{$\begin{array}{c}\text { Overall } \\
\text { Mesangat }\end{array}$} \\
\hline & 1 (Downstream) & $\begin{array}{c}2 \\
\text { (Middle) }\end{array}$ & $\begin{array}{c}3 \\
\text { (Hulu) } \\
\end{array}$ & \\
\hline Number of Species & 6 & 9 & 3 & 13 \\
\hline Number of Individuals & 51 & 135 & 34 & 220 \\
\hline Diversity Index & 1,32 & 1,03 & 0,67 & 1,55 \\
\hline Uniformity Index & 0,74 & 0,47 & 0,49 & 0,61 \\
\hline Dominance Index & 0,68 & 1 & 1 & 1 \\
\hline
\end{tabular}

Table 1:- Analysis and Calculation Results of the Diversity, Uniformity and Dominance Index of Each Observation Site

Based on Table 1 on Mesangat Wetlands shows that the diversity index is 1.55 with a dominance value of 1 and a uniformity index of 0.61. According to Odum (1993) the diversity index can be said to be moderate if the range of values is between $1-3$, which indicates that the area has land vegetation and the environment around it is supportive and adequate for the presence of herpetofauna as its habitat. Index values exceeding 0.6 are categorized as high which indicates that individual distribution is evenly distributed in the region. Whereas if the dominance index value is close to 1 , it indicates that there are species that dominate in the location of an area (Odum, 1993).

\begin{tabular}{|c|c|c|c|}
\hline \multirow{2}{*}{ Location } & \multicolumn{3}{|c|}{ Species Similarity (\%) } \\
\cline { 2 - 4 } & 1 & 2 & 3 \\
\hline 1 & - & 23,08 & 10 \\
\hline 2 & - & - & 30 \\
\hline 3 & - & - & - \\
\hline
\end{tabular}

Table 2:- Percentage of similarity types between locations using the Jaccard similarity index

Based on Table 2 shows that the location that has the highest index of similarity is between locations 2 and 3 with a percentage of $30 \%$ and the location that has the lowest percentage level of similarity is shown between location 1 and location 3 with a percentage of only $10 \%$, which indicates that the species found at locations 2 and 3 have much in common. This can be caused by environmental conditions between locations 1, 2 and location 3 are not much different, this similarity can be seen that the three locations are crossed by a stream of mesangat, so that the types of aquatic or semi-aquatic herpetofauna found are not much different.

\begin{tabular}{|c|c|c|}
\hline Parameters & Morning & Night \\
\hline Air temperature & $26,3^{0} \mathrm{C}$ & $24,3^{\circ} \mathrm{C}$ \\
\hline Water temperature & $26,3^{0} \mathrm{C}$ & $26^{0} \mathrm{C}$ \\
\hline Humidity & $71 \%$ & $74 \%$ \\
\hline $\mathrm{pH}$ & 6,5 & 6,5 \\
\hline
\end{tabular}

Table 3:- Measurement Results Mean Value of Environmental Parameters at Mesangat Hilir Location

\begin{tabular}{|c|c|c|}
\hline Parameters & Morning & Night \\
\hline Air temperature & $29^{0} \mathrm{C}$ & $28,5^{0} \mathrm{C}$ \\
\hline Water temperature & $27,5^{0} \mathrm{C}$ & $27,5^{\circ} \mathrm{C}$ \\
\hline Humidity & $91,3 \%$ & $93 \%$ \\
\hline $\mathrm{pH}$ & 6,5 & 6,5 \\
\hline
\end{tabular}

Table 4:- Results of Measurement of Mean Values of Environmental Parameters at Mesangat Tengah Location

\begin{tabular}{|c|c|c|}
\hline Paramaters & Morning & Night \\
\hline Air temperature & $30^{\circ} \mathrm{C}$ & $28^{0} \mathrm{C}$ \\
\hline Water temperature & $27^{0} \mathrm{C}$ & $29^{0} \mathrm{C}$ \\
\hline Humidity & $78 \%$ & $89 \%$ \\
\hline $\mathrm{pH}$ & 6,5 & 6,5 \\
\hline
\end{tabular}

Table 5:- Results of Measurement of Mean Values of Environmental Parameters at Mesangat Hulu 
Based on the table above shows that the air temperature at night is lower than during the day with higher humidity at night than during the day (Table 3 and Table 4). Whereas the water temperature and $\mathrm{pH}$ did not change except at the Mesangat Hulu location (Table 5) the water temperature rose at night (290C) in the morning 270C. According Rahayuningsih and Abdullah (2012) said that amphibians can live in a temperature range of $22.60 \mathrm{C}$ $28.50 \mathrm{C}$ with humidity reaching $71 \%-92 \%$ and for coldblooded animals especially reptiles generally can live in environmental conditions with temperatures ranging from 30C - 410C. Yani et al (2015) also said that herpetofauna can live at an optimum temperature of 260C - 330C. Herpetofauna in general can live in a variety of habitats both in coastal areas or in the highlands even with water temperatures between 200C - 350C (Yani et al, 2015). The $\mathrm{pH}$ measurement results are in good condition to support the life of herpetofauna. The size of the $\mathrm{pH}$ in the tropics generally has a range of $4.3-7.5$ (Yani et al, 2015).

Herpetofauna has several factors that greatly affect its existence. Ecology that supports herpetofauna such as habitat type, substrate type and environmental parameters will support the survival of herpetofauna (Porazidis and Lebrun, 2007). According to Porazidis and Lebrun (2007) Different environmental parameters such as the area of the forest canopy cover or the type of substrate will determine the microhabitat in the habitat types at the study site. These parameters include air humidity, air temperature, water temperature and water $\mathrm{pH}$ which describe the herpetofauna habitat in the Mesangat Wetland area. The presence of microhabitat is one of the important factors that play a role in determining the herpetofauna species richness compared to the heterogeneity of the landscape, the level of fragmentation or the dominant vegetation composition. In this study the types and conditions of habitats observed as well as the measured environmental parameters show that the Mesangat Wetland area is sufficient and supports the life of herpetofauna.

The Mesangat Wetlands are the original habitat of two endemic Kalimantan crocodiles, namely the Siamese crocodile (Crococodylus siamensis) and the False Gharial (Tomistoma schlegelii). Based on observations made by Kurniati et al (2005), it is found that crocodiles are found and make nests in grassy areas while False Gharials are mostly in forest areas or muddy areas with vegetation of large trees. In this study only one individual type of conjoined crocodile was observed because the water level was insufficient to access the pathway to the location where crocodiles are found.

\section{CONCLUSION}

The distribution of herpetofauna in Mesangat Wetland is quite evenly distributed, this can be seen from the presence of species and in each research location shows the species found are not much different.
The ecology of herpetofauna in Mesangat Wetlands supports the life of herpetofauna, judging by the condition and type of habitat as well as adequate environmental parameters that can support the life of herpetofauna.Diversity in Mesangat Wetlands obtained index value of 1.55 , which indicates that diversity in Mesangat Wetlands is included in the medium category.

\section{ACKNOWLEDGMENT}

Thanks to : a. East Kutai Regency Government, b. PT. Rea Kaltim, c. all parties related to the writing of this manuscript

\section{REFERENCES}

[1]. Das, I. 2004. A Pocket Guide Lizard of Borneo. Kota Kinibalu Malaysia: Natural History Publication

[2]. Gibbons, J.W., D.E Scott., T.J Ryan., KA Buhlmann., TD Tuberville., BS Metts., JL Greene., T. Mills., Y Leiden., S. Poppy., And CT, Winne. 2000. The Global Decline of Reptiles, Deja Vu Amphibians. Bioscience. (50) 8: 653-666

[3]. Kurniati, H., T. Widodo and C. Manolis. 2005. Surveys Of Siamese Crocodile (Crocodylus Siamensis) Habitat In The Mahakam River, East Kalimantan, Indonesia. Researcher Center for Biology, LIPI.

[4]. Kusumawati, W. 2009. Evaluation of Mangrove Vegetable Wetlands in Reducing Environmental Pollution (Case Study in Kepetingan Village, Sidoarjo Regency). Thesis. Diponegoro University: Semarang.

[5]. Kusrini MD, U. Adininggar, Ul-Hasanah and W. Endarwin. 2008. Introduction of Herpetofauna. Presented at the National Forestry Scientific Week, Department of Forest Resources Conservation and Ecotourism, Faculty of Forestry Bogor Agricultural University online at: http://alasyjaaripb.files.wordpress.com/2008/11/ introduction to herpetofauna2008.doc. [accessed April 15, 2019]

[6]. Ruler. 2003. Amphibious Field Guide for the Lauser Ecosystem. First printing. The Gibbon Foundation and PILI-GO Movemant: Bogor

[7]. Muslim, T. 2016. Types of Herpetofauna in Rice Fields in Samboja, East Kalimantan. Samboja Natural Resource Conservation Technology Research Center: 1-7

[8]. Muslim, T., Y. Rayadin and A. Suhardiman. 2018. Habitat Preference Based on Herpetofauna Spatial Distribution in Pt Singlurus Pratama Coal Mining Area, East Kalimantan. Agrifor Journal. Vol XVII (1): 175-190

[9]. Odum, E.P. 1993. Fundamentals of Ecology. Gadjah Mada University: Yogyakarta.

[10]. Pradana, R.A.P., Fhadilah, R.H., Aula N., Hilman, M and Amin, F. 2019. Inventory and Conservation Status of Herpetofauna Types at Watu Ondo Waterfall. Parallel Speakers Article. Vol IV: 219 - 223. 
[11]. Poirazidis, K And Lebrun, P. 2007. Diversity, Ecological Structure and Conservation of $\mathrm{Og}$ Herpetofauna in A Mediterranean Area (Dadia National Park, Greece). Amphibia-Reptilia. Vol. 28: 517-529.

[12]. Qurniawan, T.F and R. Epilurahman. 2012. Diversity of Herpetofauna Species in the Kiskendo Goa Ecotourism Area, Kulonprogo, Yogyakarta Special Province. Biota. Vol. 17 (2): 78-84

[13]. Sharney, Kyle ... S. Bruce., B. Simpson and C. Stevenson. 2019. Tomistoma Tomistoma schlegelii. Pp. $\mathrm{xx}-\mathrm{xx}$ in Crocodiles. Status of Survey and Conservation Action Plan. Fourth Edition. Crocodile Specialist Group: Darwin

[14]. Yani, A., S. Said and Erianto. 2015. Diversity of Amphibians of the Anura Order in the Mount Semahung Protected Forest Area, Sengah Temila District, Landak Regency, West Kalimantan. Journal of Sustainable Forests. Vol 3 (1): 15-20

[15]. (20) Yudha, D.S., R. Eprilurahman., H. Jayanto and I.F. Wiryawan. 2016. Diversity of Jnis Lizards and Snakes (Squamata: Reptiles) River Code, Yogyakarta Special Region. Biota Vol 1 (1): 31 - 38 